\title{
Different benthic size-compartments and their relationship to sediment chemistry in the deep Eurasian Arctic Ocean
}

\author{
Ingrid Kröncke ${ }^{1, *}$, Ann Vanreusel ${ }^{2}$, Magda Vincx ${ }^{2}$, Jutta Wollenburg ${ }^{3}$, \\ Andreas Mackensen ${ }^{3}$, Gerd Liebezeit ${ }^{4}$, Brigitte Behrends ${ }^{4}$
}

\footnotetext{
${ }^{1}$ Senckenberg Institute, Department for Marine Research, Schleusenstr. 39a, 26382 Wilhelmshaven, Germany

${ }^{2}$ University of Gent, Zoology Institute, Marine Biology Section, K.L. Ledeganckstraat 35, 9000 Gent, Belgium ${ }^{3}$ Alfred-Wegener-Institute for Polar and Marine Research, POB 120161, 27515 Bremerhaven, Germany

${ }^{4}$ Terramare Research Centre, Schleusenstr. 1, 26382 Wilhelmshaven, Germany
}

\begin{abstract}
During the Arctic Expedition ARK VIIV3 (August to September 1991) with RV 'Polarstern', the macrofauna, meiofauna, foraminifera, bacteria were sampled and sediment chemistry was determined at 13 stations along a transect from the Barents Sea slope across the deep Arctic Eurasian Basins towards the Lomonosov Ridge. Water depths ranged from 258 to $4427 \mathrm{~m}$. In general, higher values for all benthic compartments as well as total organic carbon (TOC) and total hydrolysable amino acids (THAA) were recorded for the Barents Sea slope than for the deeper stations in the basins and the ridge slopes. The only significant correlation found was between macrofaunal abundance and depth. Bacterial and all faunal abundances as well as bacterial and macrofaunal biomass decreased significantly with increasing latitude. Although correlations between food items such as TOC and THAA and the fauna were weak, significant relationships between the bacterial and faunal size-classes reflected a distinct food chain typical of oligotrophic systems. The smallest compartments-bacteria, meiofauna and foraminifera - were more abundant than the macrofauna in the central Arctic Ocean. Macrofauna biomass dominated the biomass on the Barent Sea shelf and slope and on the Lomonosov Ridge, but bacterial biomass was equally or even more important on the Gakkel Ridge and in the deep basins. The results reveal the Eurasian Basin as one of the most oligotrophic regions in the World Ocean. Although primary production is low, recent foraminiferal investigations have revealed that benthic communities in the central Arctic Ocean are driven by the sedimentation of fresh organic material. Lateral transport of organic material from the Siberian shelf may provide additional food. The various benthic compartments compete either for fresh organic matter or for refractory material that is transferred to higher levels of the food chain by bacterial mineralisation.
\end{abstract}

KEY WORDS: Arctic Ocean - Deep-sea - Bacteria - Foraminifera - Meiofauna - Macrofauna - TOC . Amino acids $\cdot$ Chloroplastic pigments $\cdot$ C-flux

\section{INTRODUCTION}

Covering an area of $14.6 \times 10^{6} \mathrm{~km}^{2}$, the Arctic Ocean is the largest intercontinental mediterranean sea on earth. It has a mean permanent ice cover of $9.3 \times$ $10^{6} \mathrm{~km}^{2}$ in summer that can increase to as much as $15.7 \times 10^{6} \mathrm{~km}^{2}$ in winter (Gloersen et al. 1992). In the Eurasian sector, mean ice thickness is between 1 and $2 \mathrm{~m}$ (Kolatschek et al. 1996). It takes 3 to $4 \mathrm{yr}$ for the ice to move from East Siberia to the Fram Strait, through

•E-mail: ingrid.kroencke@sam.terramare.de which $\sim 20 \%$ of the ice volume of the Arctic basin is annually exported (Thorndike \& Colony 1985). Sea ice is transported by the Transpolar Drift from the Siberian shelf areas through the central Arctic to the Fram Strait.

The Lomonosov Ridge divides the Arctic Ocean into 2 deep basins, the Eurasian and the Canadian Basin. At the ridge, a sharp salinity front separates the fresh waters of the Canadian Basin from the saltier waters of the Eurasian Basin (Steele \& Boyd 1998). Relatively warm water-masses of Atlantic origin enter the Arctic Ocean via the West Spitzbergen Current and the Barents Sea branch (Rudels et al. 1994). There are 3 dif- 
ferent water layers in the Arctic Ocean: the cold, fresh, mixed, surface layer $(0 \text { to } 50 \mathrm{~m})_{\text {; }}$ the cold, salty, halocline layer $(50$ to $120 \mathrm{~m})$; the warm, Atlantic layer $(>120 \mathrm{~m}$ ) (Aagard et al. 1985, Steele \& Boyd 1998).

Primary production in the permanently ice-covered Arctic Ocean is much lower than in other oligotrophic oceans, and is restricted to the upper $100 \mathrm{~m}$ of the water column (Alexander 1980, Andersen 1989, Wheeler et al. 1996). Primary production, including water column and ice algae, is usually $\sim 10 \mathrm{~g} \mathrm{C} \mathrm{m}^{-2} \mathrm{yr}^{-1}$ in the central Arctic Ocean (Wheeler et al. 1996). Because of degradation of particles during sinking and a relative high grazing pressure (Wassmann et al. 1991, Wheeler et al. 1996), only a small fraction of this organic material reaches the sea-floor.

During the 1930 s to 1950 s, a number of Russian cruises explored the macrofauna of the Arctic shelves and the basins up to $78^{\circ} \mathrm{N}$ (Zenkevitch 1963, Koltun \& Blakschin 1964). Before 1991, benthic investigations were carried out in the Canadian Archipelago by Paul $\&$ Menzies (1974) and Thompson (1982) between $75^{\circ}$ and $85^{\circ} \mathrm{N}$. Few studies investigated foraminifera of the central Eurasian Basin (Scott \& Vilks 1991).

The 'Polarstern' expedition ARK VIII/3 (August to October 1991) (Fütterer 1992) provided for the first time an opportunity to investigate the benthic communities of the central deep Arctic Ocean. The data collected during this expedition provided the first descriptions of the macrofaunal (Kröncke 1994, 1998), meiofaunal (Vanreusel et al. 1999), foraminiferal (Bergsten 1994, Wollenburg 1995, Wollenburg \& Mackensen 1998a,b), and bacterial (Kröncke et al. 1994) communities of the Eurasian Basin.

It is known from other deep-sea areas that the body size of benthic organisms decreases with increasing depth (Thiel 1979, Tietjen et al. 1989, Rowe et al. 1991, Tselepides \& Eleftheriou 1992).

The present synthesis of the various benthic compartments sampled in 1991 from the same location enables us to determine whether the size structure of the benthic communities in the Arctic Ocean follows the same tendency as in other deep-sea areas of the World Ocean; i.e. if the smaller-sized benthic compartments become relatively more important than the macrofaunal compartments with increasing depth. Furthermore, the availability of food via vertical sedimentation or lateral transport of organic material from the Siberian shelf is discussed.

\section{MATERIALS AND METHODS}

During the 'Polarstern' Expedition ARK VIII/3, the benthic compartments bacteria, meiofauna, foraminifera, and macrofauna were sampled, and sediment chemistry determined, at 13 stations. Samples were taken in August and September 1991 along a transect from Northern Svalbard through the Eurasian Basin on to the Makarov Basin (Table 1, Fig. 1) at depths ranging from 258 to $4427 \mathrm{~m}$.

Sampling was carried out with a $0.25 \mathrm{~m}^{2}$ USNEL box corer ( 1 per station). From each core, sub-samples of bacteria, meiofauna and macrofauna and sediment were taken for analysis. Samples for foraminiferal investigation were taken with a multicorer.

Sub-samples $\left(0.02 \mathrm{~m}^{2}\right)$ for macrofaunal analysis were taken from the main core. Between 1 and 7 subsamples per core were taken (the main core had to be shared between different working groups). The samples were washed over $0.5 \mathrm{~mm}$ mesh size and fixed in $4 \%$ buffered formalin. Wet weight was used for biomass measurements to avoid the necessity of combusting the samples (Kröncke 1994).

Bacterial samples were taken with $10 \mathrm{~mm}$ diameter cut-off syringes to determine variations in the bacterial distributions. Two replicates of 0 to $2 \mathrm{~cm}$ sediment depth were fixed in $3 \%$ formalin. Bacterial abundance was determined by acridine-orange direct counts. Bacterial cells were morphologically differentiated into 5 size groups, and each group was counted quantitatively. Bacterial organic carbon content was calculated from mean biovolume using a conversion factor (for details see Kröncke et al. 1994).

For meiofauna analysis, 2 replicate samples each were taken with a $3.5 \mathrm{~cm}$ diameter tube at 0 to 2 and 2 to $10 \mathrm{~cm}$ sediment depth. The samples were fixed with $4 \%$ neutral formalin. Samples were elutriated in the laboratory by LUDOX AM centrifugation on a $38 \mu \mathrm{m}$ sieve. Counting was performed under a binocular microscope. From each replicate, up to 150 nematodes were mounted on slides and measured for bio-

Table 1. Positions and water depths of stations at Barents Sea shelf (BS), Nansen Basin (NB), Gakkel Ridge (GR), Amundsen Basin (AB), Lomonosov Ridge (LR) and Makarov Basin (MB)

\begin{tabular}{|lccc|}
\hline Stn no. & Area & Lat. E Long. N & Depth (m) \\
\hline 2156 & BS & $030^{\circ} 13.80 ; 80^{\circ} 05.20$ & 258 \\
2157 & NB & $029^{\circ} 59.97 ; 81^{\circ} 45.32$ & 2950 \\
2158 & NB & $029^{\circ} 55.51 ; 82^{\circ} 46.56$ & 3800 \\
2159 & NB & $030^{\circ} 20.70 ; 83^{\circ} 57.38$ & 3950 \\
2162 & NB & $050^{\circ} 49.60 ; 85^{\circ} 47.69$ & 3981 \\
2163 & GR & $059^{\circ} 14.03 ; 86^{\circ} 14.54$ & 3047 \\
2164 & GR & $059^{\circ} 17.76 ; 86^{\circ} 19.95$ & 2035 \\
2167 & GR & $059^{\circ} 04.45 ; 86^{\circ} 56.11$ & 4425 \\
2168 & GR & $055^{\circ} 56.01 ; 87^{\circ} 30.62$ & 3845 \\
2171 & AB & $068^{\circ} 58.63 ; 87^{\circ} 35.14$ & 4384 \\
2174 & AB & $091^{\circ} 41.19 ; 87^{\circ} 29.08$ & 4427 \\
2177 & LR & $134^{\circ} 53.71 ; 88^{\circ} 02.16$ & 1388 \\
2184 & LR & $148^{\circ} 12.12 ; 87^{\circ} 36.67$ & 1654 \\
\hline
\end{tabular}




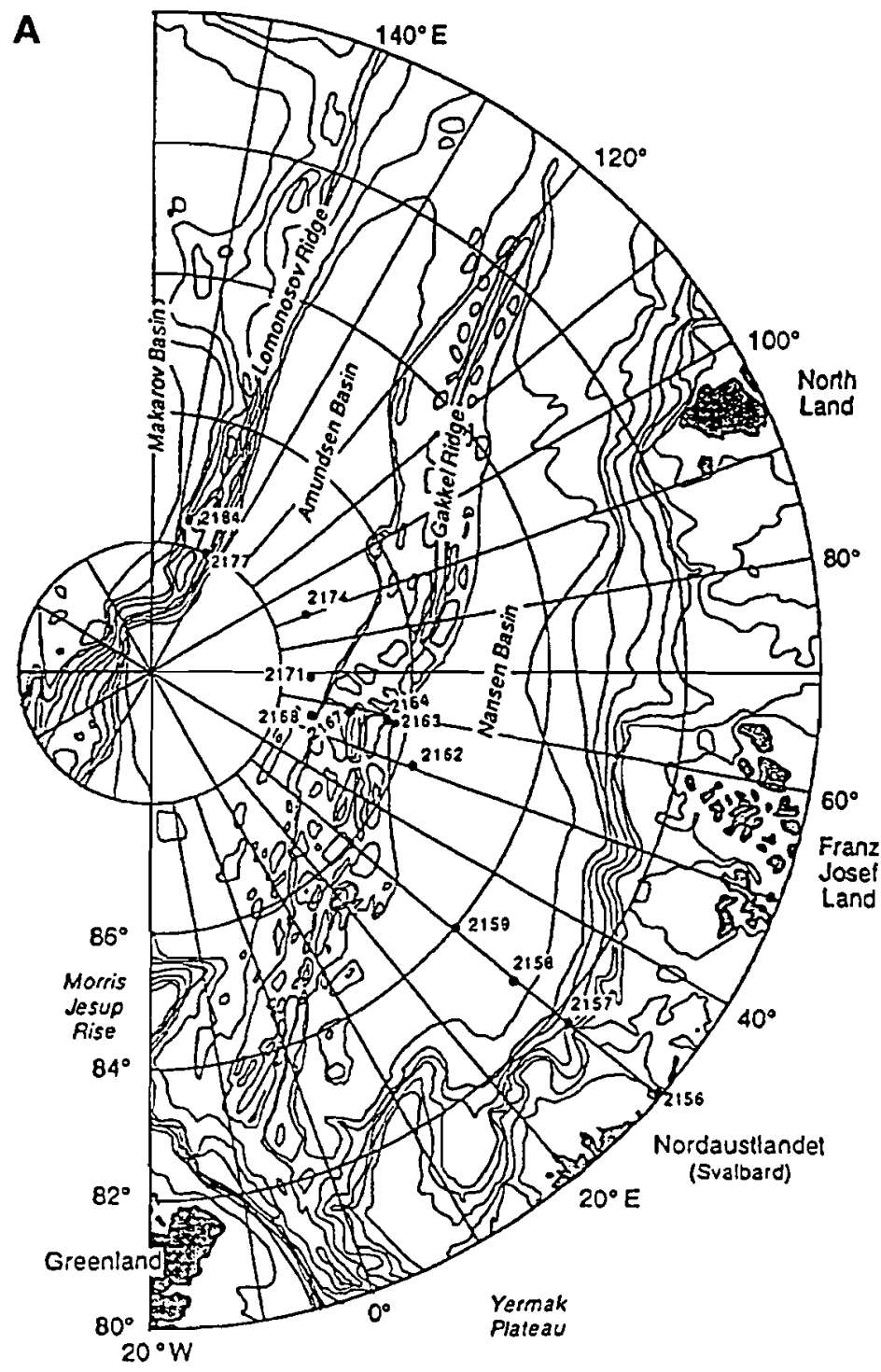

mass calculations. For this study, only data for the 0 to $2 \mathrm{~cm}$ layer were considered.

For foraminiferal investigations, surface sediment $(0$ to $1 \mathrm{~cm}$ ) was taken from 3 to 6 multicorer tubes and fixed in 'Rose Bengal solution', as described by Wollenburg (1995). For biomass determination (with shell) the foraminifera were analysed using a CHN analyser (Elementar Analysen 'vario el'). Wet weight was determined by multiplying the carbon content by a factor of 10 , the mean conversion factor for macrofauna (Salzwedel et al. 1985).

Surface $(0$ to $2 \mathrm{~cm})$ sediment samples intended for chemical analysis were stored at $-20^{\circ} \mathrm{C}$ during transport. After thawing, the samples were dried to constant weight at $70^{\circ} \mathrm{C}$ and then used without further treatment. Total organic carbon (TOC) was determined by hightemperature oxidation using a CHNS analyser (Elementar Analysen, vario el). Prior to analysis, carbonates were removed by treating the samples with concentrated $\mathrm{HCl}$ vapour in a desiccator.

Total hydrolysable amino acids (THAA) were analysed by HPLC as their isoindole derivatives, after hydrolysis at $110^{\circ} \mathrm{C}$ for $24 \mathrm{~h}$ under nitrogen (Behrends \& Liebezeit 1999).

For pignent determination, $500 \mathrm{mg}$ of dried sediment were extracted with $5 \mathrm{ml}$ each $90 \%$ aqueous acetone in the dark for $30 \mathrm{~min}$ after an inital $3 \mathrm{~min}$ ultrasonic treatment. Extracts were analysed by spectrophotometry. Quantification was against chlorophyll a (Sigma, Munich) using the $\alpha$ band at $-660 \mathrm{~nm}$.

Correlations were carried out using Pearson's product moment.
8

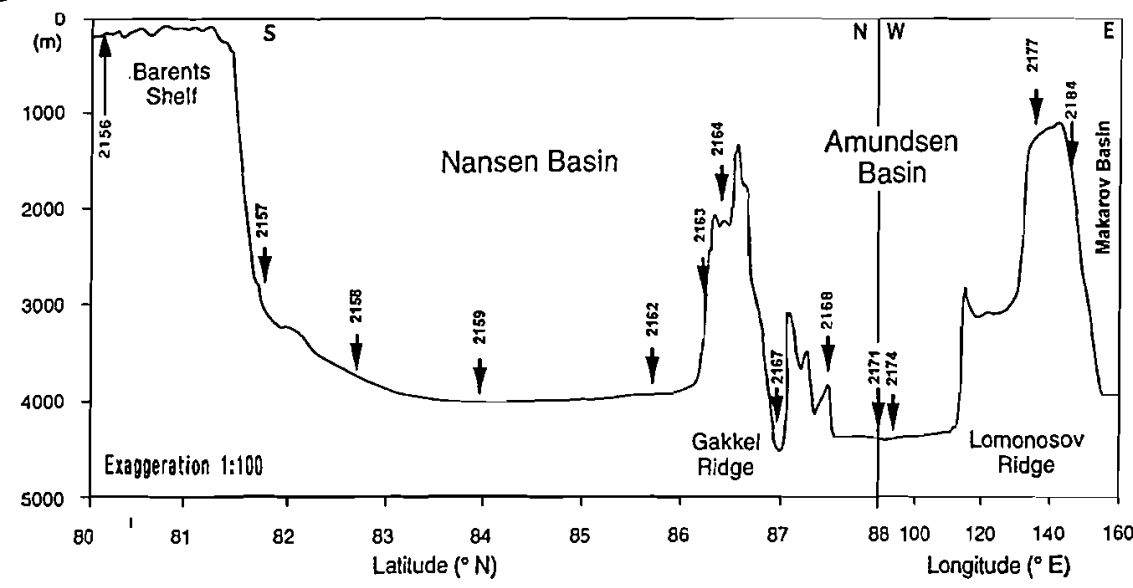

Fig. 1. (A) Positions of stations ( $\bullet$ ) on Barents Sea shelf, in Nansen Basin, on Gakkel Ridge, in Amundsen Basin, on Lomonosov Ridge and in Makarov Basin; (B) depth profile along transect

\section{RESULTS}

\section{Benthic compartments}

In general, all benthic compartments displayed higher abundance and biomass on the Barents Sea shelf and slope than in the deep basins or the ridges (Tables $2 \& 3$ ).

Bacterial numbers varied between $2.37 \times 10^{12}$ and $8.9 \times 10^{11} \mathrm{~m}^{-2}$. Foraminifera in the $>63$ to $<125 \mu \mathrm{m}$ size class occurred at densities of $2.67 \times 10^{4}$ to $1.07 \times 10^{3}$ ind. $\mathrm{m}^{-2}$, larger foraminifera (>125 $\mathrm{\mu m})$ at densities of $1.02 \times 10^{4}$ to $3.37 \times$ $10^{2}$ ind. $\mathrm{m}^{-2}$. Meiofauna numbers 
Table 2. Abundance (nos. $\mathrm{m}^{-2}$ ) of various benthic compartments

\begin{tabular}{|llllll|}
\hline Stn & Bacteria & Meiofauna & \multicolumn{2}{c}{ Foraminifera } & Macrofauna \\
& & & $>63<125 \mu \mathrm{m}$ & $>125 \mu \mathrm{m}$ & \\
\hline 2156 & $2.37 \times 10^{12}$ & $2.11 \times 10^{5}$ & $2.51 \times 10^{4}$ & $1.01 \times 10^{4}$ & $4.83 \times 10^{3}$ \\
2157 & $1.89 \times 10^{12}$ & $1.54 \times 10^{5}$ & $2.67 \times 10^{4}$ & $1.02 \times 10^{4}$ & $9.50 \times 10^{2}$ \\
2158 & $1.62 \times 10^{12}$ & & $2.00 \times 10^{4}$ & $9.00 \times 10^{3}$ & $1.25 \times 10^{2}$ \\
2159 & $1.86 \times 10^{12}$ & $5.10 \times 10^{3}$ & $1.46 \times 10^{4}$ & $1.13 \times 10^{3}$ & $7.50 \times 10^{1}$ \\
2162 & $1.26 \times 10^{12}$ & & $1.11 \times 10^{3}$ & $3.57 \times 10^{2}$ & $1.50 \times 10^{2}$ \\
2163 & $1.52 \times 10^{12}$ & $1.36 \times 10^{4}$ & $9.11 \times 10^{3}$ & $3.70 \times 10^{3}$ & $0.00 \times 10^{0}$ \\
2164 & $1.54 \times 10^{12}$ & & $2.17 \times 10^{4}$ & $3.14 \times 10^{3}$ & $5.00 \times 10^{1}$ \\
2167 & $1.17 \times 10^{12}$ & & $1.07 \times 10^{3}$ & $3.39 \times 10^{2}$ & $5.00 \times 10^{1}$ \\
2168 & $9.50 \times 10^{11}$ & & $7.50 \times 10^{3}$ & $8.34 \times 10^{2}$ & $5.00 \times 10^{1}$ \\
2171 & $1.31 \times 10^{12}$ & $1.90 \times 10^{3}$ & $5.18 \times 10^{3}$ & $1.88 \times 10^{3}$ & $2.00 \times 10^{2}$ \\
2174 & $1.15 \times 10^{12}$ & & $2.08 \times 10^{3}$ & $1.75 \times 10^{3}$ & $7.50 \times 10^{1}$ \\
2177 & $1.06 \times 10^{12}$ & $1.28 \times 10^{4}$ & $1.57 \times 10^{4}$ & $2.38 \times 10^{3}$ & $2.50 \times 10^{2}$ \\
2184 & $8.90 \times 10^{11}$ & $1.28 \times 10^{4}$ & $8.49 \times 10^{3}$ & $5.83 \times 10^{3}$ & $2.00 \times 10^{2}$ \\
& & & & & \\
\hline
\end{tabular}

meiofauna was the second most abundant group, whereas in the Nansen and Amundsen Basins (Stns 2158 to 2162,2171 to 2174 ), the $>63$ to $<125 \mu \mathrm{m}$ foraminifera were the second most abundant group. Meiofaunal abundance data were, however, not available for all stations. On the ridges (Stns 2163, 2164 and 2177), meiofauna as well as foraminifera ( $>63$ to $<125 \mu \mathrm{m})$ abundance increased (Stns 2163, 2164, 2168, 2177, 2184) significantly compared to their abundance in the basins.

From a total of 13 stations, we obtained biomass data from 3 stations for all compartments and from 7 stations for bacteria, meiofauna and macrofauna

Table 3. Biomass $\left(\mathrm{g}\right.$ wet $\mathrm{wt} \mathrm{m}^{-2}$ ) of various benthic compartments

\begin{tabular}{|lcccc|}
\hline St & Bacteria & Meiofauna & Foraminifera & Macrofauna \\
\hline 2156 & $1.50 \times 10^{-1}$ & $1.64 \times 10^{-1}$ & & $9.05 \times 10^{1}$ \\
2157 & $1.00 \times 10^{-1}$ & $3.50 \times 10^{-2}$ & $4.00 \times 10^{-1}$ & $8.27 \times 10^{1}$ \\
2158 & $1.10 \times 10^{-1}$ & & & $5.00 \times 10^{-1}$ \\
2159 & $1.00 \times 10^{-1}$ & $3.35 \times 10^{-4}$ & & $1.50 \times 10^{-1}$ \\
2162 & $1.00 \times 10^{-1}$ & & & $1.25 \times 10^{0}$ \\
2163 & $1.10 \times 10^{-1}$ & $2.00 \times 10^{-3}$ & & $0.00 \times 10^{0}$ \\
2164 & $1.30 \times 10^{-1}$ & & $8.80 \times 10^{-2}$ & $1.00 \times 10^{-1}$ \\
2167 & $8.00 \times 10^{-2}$ & & & $5.00 \times 10^{-2}$ \\
2168 & $5.00 \times 10^{-2}$ & & & $1.00 \times 10^{-1}$ \\
2171 & $7.00 \times 10^{-2}$ & $1.54 \times 10^{-4}$ & & $2.00 \times 10^{-1}$ \\
2174 & $8.00 \times 10^{-2}$ & & & $8.00 \times 10^{-2}$ \\
2177 & $6.00 \times 10^{-2}$ & $1.92 \times 10^{-3}$ & $3.00 \times 10^{-2}$ & $2.05 \times 10^{0}$ \\
2184 & $5.00 \times 10^{-2}$ & $6.88 \times 10^{-3}$ & & $2.80 \times 10^{-1}$ \\
& & & & \\
\hline
\end{tabular}

ranged from $2.11 \times 10^{5}$ to $1.90 \times 10^{3} \mathrm{~m}^{-2}$, macrofauna abundances from 4830 to 0 ind. $\mathrm{m}^{-2}$.

The biomass patterns for bacteria, meiofauna, foraminifera and macrofauna were similar. Bacterial biomass ranged between $1.5 \times 10^{-1}$ and $5 \times 10^{-2} \mathrm{~g}$ wet wt (WW) per $\mathrm{m}^{2}$, foraminiferal biomass between 0.4 and $0.03 \mathrm{~g}(\mathrm{WW}) \mathrm{m}^{-2}$, meiofaunal biomass between 0.164 and $1.54 \times 10^{-4} \mathrm{~g}(\mathrm{WW}) \mathrm{m}^{-2}$, and macrofaunal biomass between 90.5 and $0 \mathrm{~g}(\mathrm{WW}) \mathrm{m}^{-2}$.

\section{Relative importance of various benthic compartments}

Fig. 2 shows the relative importance in abundance of the various size groups. Bacteria were always dominant. In Fig. 2, bacterial abundance has been transformed $\times 10^{5}$ to illustrate the relative importance of the other size groups. Fig. 2 clearly illustrates that on the Barents Sea shelf and slope (Stns 2156 and 2157) the
(Table 3, Fig. 3). Despite the low number of data, it is clear that macrofauna biomass dominated on the Barents Sea shelf and slope and at the Lomonosov Ridge (Stns $2177 \& 2184$ ). At the Gakkel Ridge and in the deep basins, however, bacteria and foraminifera (Stn 2164) biomass was equally or even more important.

\section{Sediment chemistry}

The total organic carbon content (TOC) at Stns 2156 and 2157 on the Barents Sea slope was $>1.5 \%$, at the Ridge Stns 2163 and 2164 (Gakkel Ridge) and 2184 (Lomonosov Ridge), TOC was $<0.5 \%$ (Table 4 ). Although there was a tendency of decreasing values with increasing water depth (Table 5), this was statistically not significant. In contrast, there was a significant correlation between TOC and total hydrolysable amino acids (THAA) and latitude (Table 5, Fig. 4A).

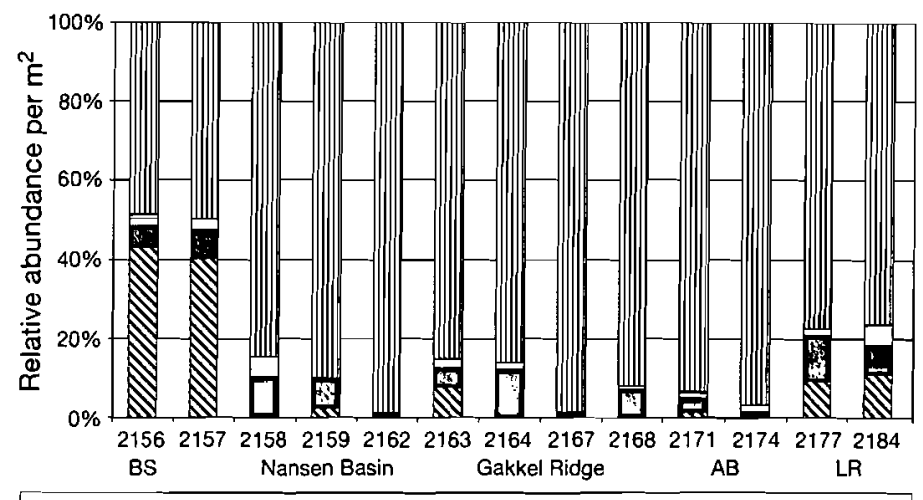

$\mathbb{D}$ meiofauna $\mathbf{D}$ foraminifera $>63<125 \mu \mathrm{m}$ 口foraminifera $>125 \mu \mathrm{m}$ 貝macrofauna 血 bacteria

Fig. 2. Relative abundance of the various benthic compartments (bacterial abundance transformed to $\times 10^{5}$ ). BS: Barents Sea shelf; AB: Amundsen Basin; LR: Lomonosov Ridge; nos. on abscissa $=$ stations 


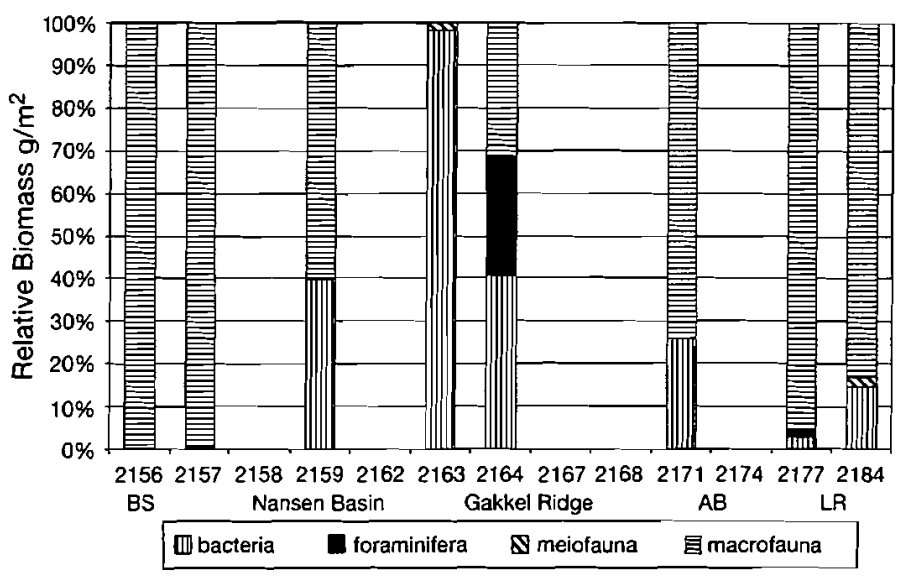

Fig. 3. Relative biomass of the different benthic compartments

Table 4. Sediment (sed) composition and chemistry (TOC: total organic carbon; THAA: total hydrolisable amino acids; CPE: chloroplastic equivalents)

\begin{tabular}{|c|c|c|c|c|c|}
\hline Stn & TOC & $\begin{array}{c}\text { Sum THAA } \\
\left(\mu \mathrm{mol} g^{-1} \text { sed }\right)\end{array}$ & $\begin{array}{c}\mathrm{CPE} \\
\left(\mu \mathrm{g} \mathrm{g}^{-1} \text { sed }\right)\end{array}$ & $\begin{array}{l}\text { Mud fra } \\
<63 \mu \mathrm{m}\end{array}$ & $\begin{array}{l}\text { ction (\%) } \\
<20 \mu \mathrm{m}\end{array}$ \\
\hline 2156 & 1.49 & 94.26 & 2.3 & 53.70 & 35.90 \\
\hline 2157 & 1.73 & 52.05 & $<0.4$ & 47.20 & 51.80 \\
\hline 2158 & 0.88 & 27.94 & $<0.4$ & 44.30 & 52.60 \\
\hline 2159 & 0.75 & 27.67 & $<0.4$ & 38.30 & 59.10 \\
\hline 2162 & 0.93 & 17.07 & $<0.4$ & 20.00 & 78.30 \\
\hline 2163 & 0.51 & 8.39 & $<0.4$ & 21.10 & 43.60 \\
\hline 2164 & 0.32 & 12.37 & $<0.4$ & 53.60 & 24.30 \\
\hline 2167 & 0.50 & 13.78 & $<0.4$ & 36.00 & 11.20 \\
\hline 2168 & 0.52 & 13.86 & $<0.4$ & 41.30 & 37.30 \\
\hline 2171 & 0.65 & 32.04 & $<0.4$ & 23.10 & 75.10 \\
\hline 2174 & 0.63 & 0.00 & $<0.4$ & 40.90 & 57.30 \\
\hline 2177 & 0.76 & 124.24 & $<0.4$ & 38.80 & 57.30 \\
\hline 2184 & 0.19 & 15.29 & $<0.4$ & 50.90 & 25.50 \\
\hline
\end{tabular}

In Samples 2177 and 2184 from the Lomonosov Ridge, the TOC-normalised THAA deviated positively from the decrease with increasing latitude (Fig. 4B). The mean amino acid spectrum was dominated by aspartic and glutamic acids, glycine (+ threonine), alanine, tyrosine, arginie and leucine with contributions around $10 \mathrm{~mol} \%$.
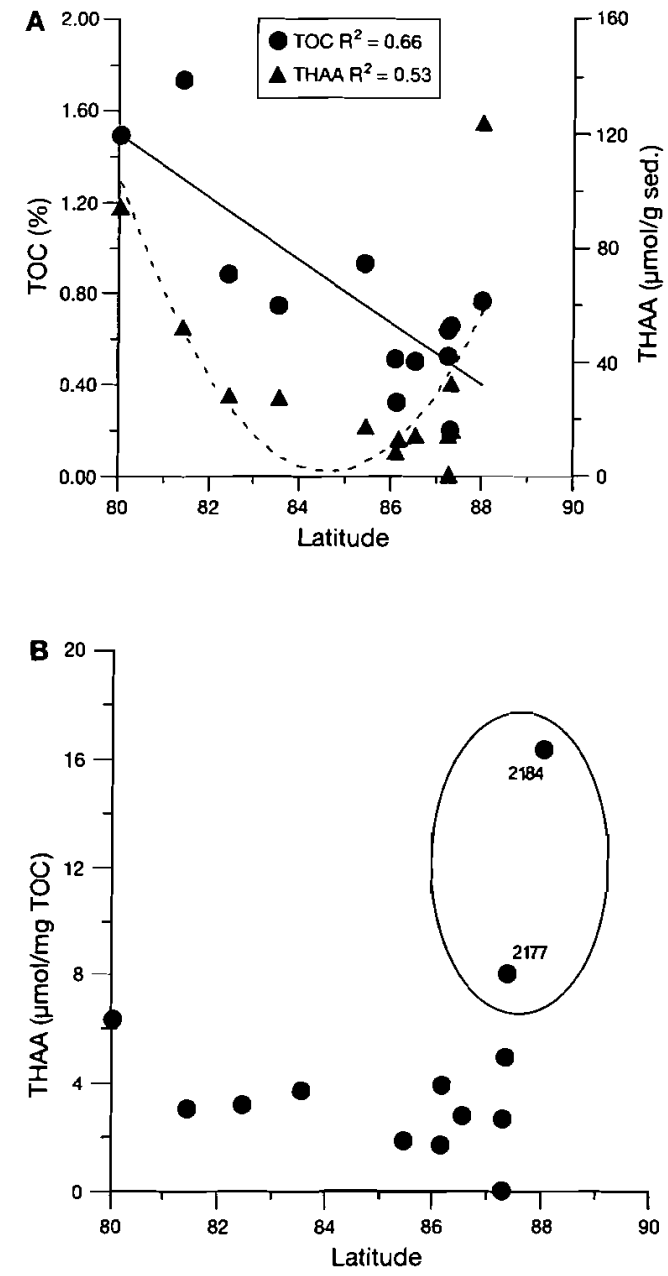

Fig. 4. Relationships (A) between TOC and THAA and latitude and $(B)$ between TOC-normalised THAA and latitude. TOC: total inorganic carbon; THAA: total hydrolysable amino acids; circled stations in $B$ from Lomonosov Ridge

Chloroplastic pigment content was extremely low and, with the exception of Stn 2156 on the Barents Sea slope, always below the detection limit of $0.4 \mu \mathrm{g} \mathrm{g}^{-1}$ sediment (Table 4).

Table 5. Pearson's product-moment correlations between abundance of benthic compartments and environmental parameters. $* 5 \% ; \cdots 1 \% ; \cdots 0.1 \%$ confidence limit

\begin{tabular}{|c|c|c|c|c|c|c|c|c|c|c|c|}
\hline & \multirow[t]{2}{*}{ Bacteria } & \multirow{2}{*}{$\begin{array}{l}\text { Meio- } \\
\text { fauna }\end{array}$} & \multicolumn{2}{|c|}{ Foraminifera } & \multirow{2}{*}{$\begin{array}{l}\text { Macro- } \\
\text { fauna }\end{array}$} & \multirow[t]{2}{*}{ Depth } & \multirow[t]{2}{*}{ Latitude } & \multirow[t]{2}{*}{ THAA } & \multirow[t]{2}{*}{ TOC } & \multicolumn{2}{|c|}{ Mud fraction } \\
\hline & & & $>63<125 \mu \mathrm{m}$ & $>125 \mu \mathrm{m}$ & & & & & & $<63 \mu \mathrm{m}$ & $<20 \mu \mathrm{m}$ \\
\hline Bacteria & & - & $*$ & • & *. & ns & $\cdots$ & ns & ** & ns & ns \\
\hline Meiofauna & - & & $\bullet$ & $\cdots$ & 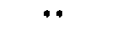 & $\cdot$ & $*$ & ns & 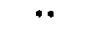 & ns & ns \\
\hline \multicolumn{12}{|l|}{ Foraminifera } \\
\hline$>63<125 \mu \mathrm{m}$ & $* *$ & $\cdots$ & & $\cdots$ & * & * & $*$ & $\cdot$ & * & $\cdot$ & ns \\
\hline$>125 \mu \mathrm{m}$ & - & $\cdots$ & $\cdots *$ & & - & • & $\cdots$ & ns & - & ns & ns \\
\hline Macrofauna & ** & ** & ns & * & & 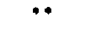 & $* *$ & * & - & ns & ns \\
\hline THAA & ns & ns & $\cdot$ & ns & * & ns & $\cdots$ & & - & ns & ns \\
\hline TOC & $\cdot \cdot$ & ** & - & * & * & ns & ** & * & & ns & $\mathrm{ns}$ \\
\hline
\end{tabular}



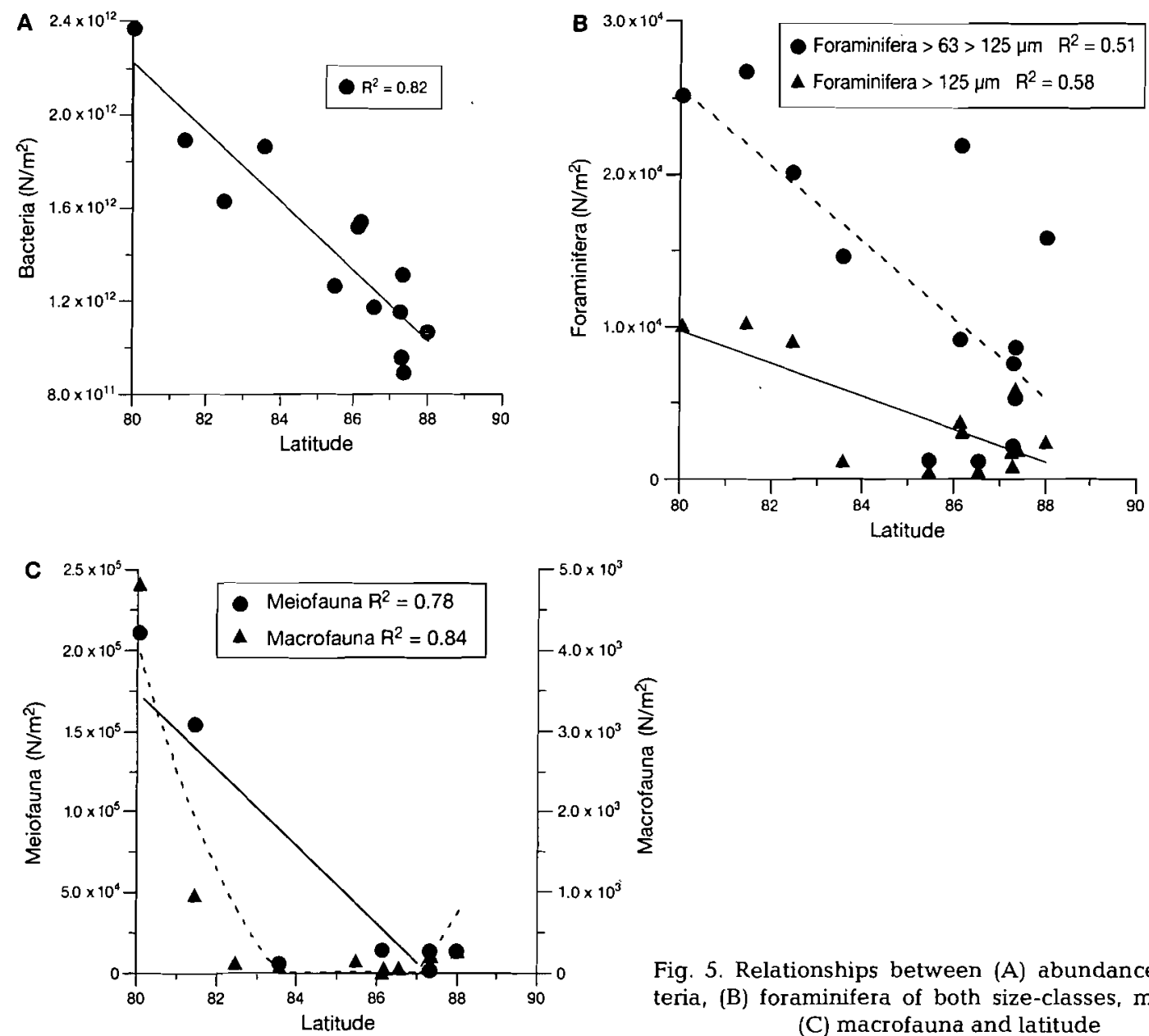

Fig. 5. Relationships between (A) abundance of bacteria, (B) foraminifera of both size-classes, meio- and (C) macrofauna and latitude

\section{Relationships between benthic compartments and environmental conditions}

A significant correlation for depth was only found with macrofaunal abundance. Bacterial and all faunal abundances as well as bacterial and macrofaunal biomass decreased significantly with increasing latitude (Tables 5 \& 6, Fig. 5).

With regard to food availability, correlations were examined between the different benthic compartments and TOC and THAA. Significant correlations were found only between bacterial and meiofaunal abundance and between macrofaunal biomass and
TOC (Table 5). No correlation was found with THAA, nor with the mud fractions $<20$ and $<63 \mu \mathrm{m}$.

The abundance of $>63$ to $<125 \mu \mathrm{m}$ foraminifera increased significantly with increasing bacterial and meiofaunal abundance (Fig. 6). The abundance of $>125 \mu \mathrm{m}$ foraminifera paralleled the abundance of meiofauna and the smaller foraminifera size-class (Table 5). A slight relationship was also found between both foraminifera size-groups and TOC (Fig. 7). Macrofaunal abundance was significantly correlated with both bacterial and meiofaunal abundance (Fig. 8). However, these latter relationships were influenced by the high values from the Barents Sea shelf.

Table 6. Pearson's product-moment correlations between biomass of benthic compartments and environmental parameters. ${ }^{-5} 5 \%{ }^{*} 1 \% ;{ }^{* *} 0.1 \%$ confidence limit. Foraminifera were omitted because of small number of data

\begin{tabular}{|c|c|c|c|c|c|c|c|c|c|}
\hline & \multirow[t]{2}{*}{ Bacteria } & \multirow[t]{2}{*}{ Meiofauna } & \multirow[t]{2}{*}{ Macrofauna } & \multirow[t]{2}{*}{ Depth } & \multirow[t]{2}{*}{ Latitude } & \multirow[t]{2}{*}{ THAA } & \multirow[t]{2}{*}{ TOC } & \multicolumn{2}{|c|}{ Mud fraction } \\
\hline & & & & & & & & $<63 \mu \mathrm{m}$ & $<20 \mu \mathrm{m}$ \\
\hline Bacteria & & - & ns & ns & ** & ns & ns & ns & ns \\
\hline Meiofauna & * & & $* *$ & ns & $\cdot$ & ns & ns & ns & ns \\
\hline Macrofauna & ns & $*$ & & ns & $\cdots$ & ns & $\cdots$ & ns & ns \\
\hline
\end{tabular}




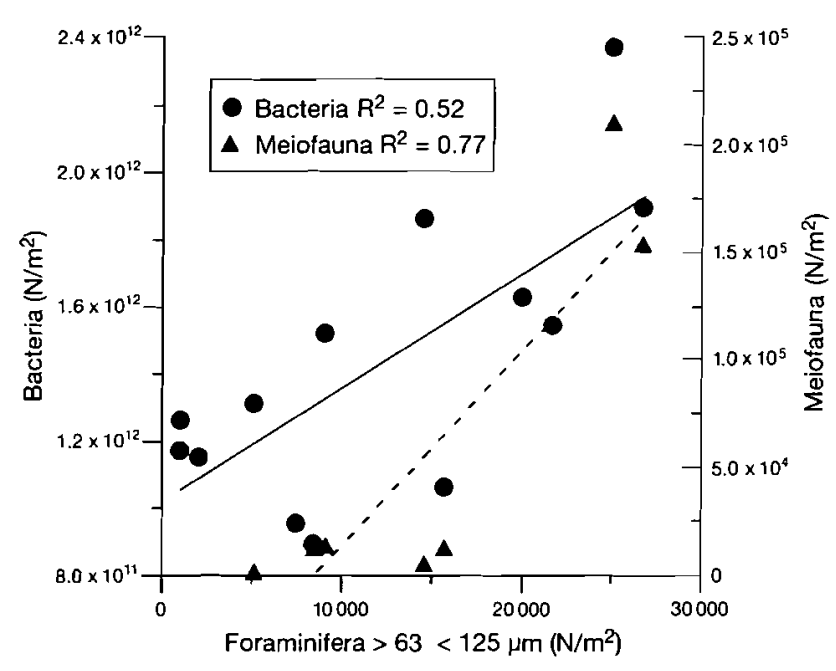

Fig. 6. Relationships between bacteria, meiofauna and foraminifera $>63<125 \mu \mathrm{m}$ abundance
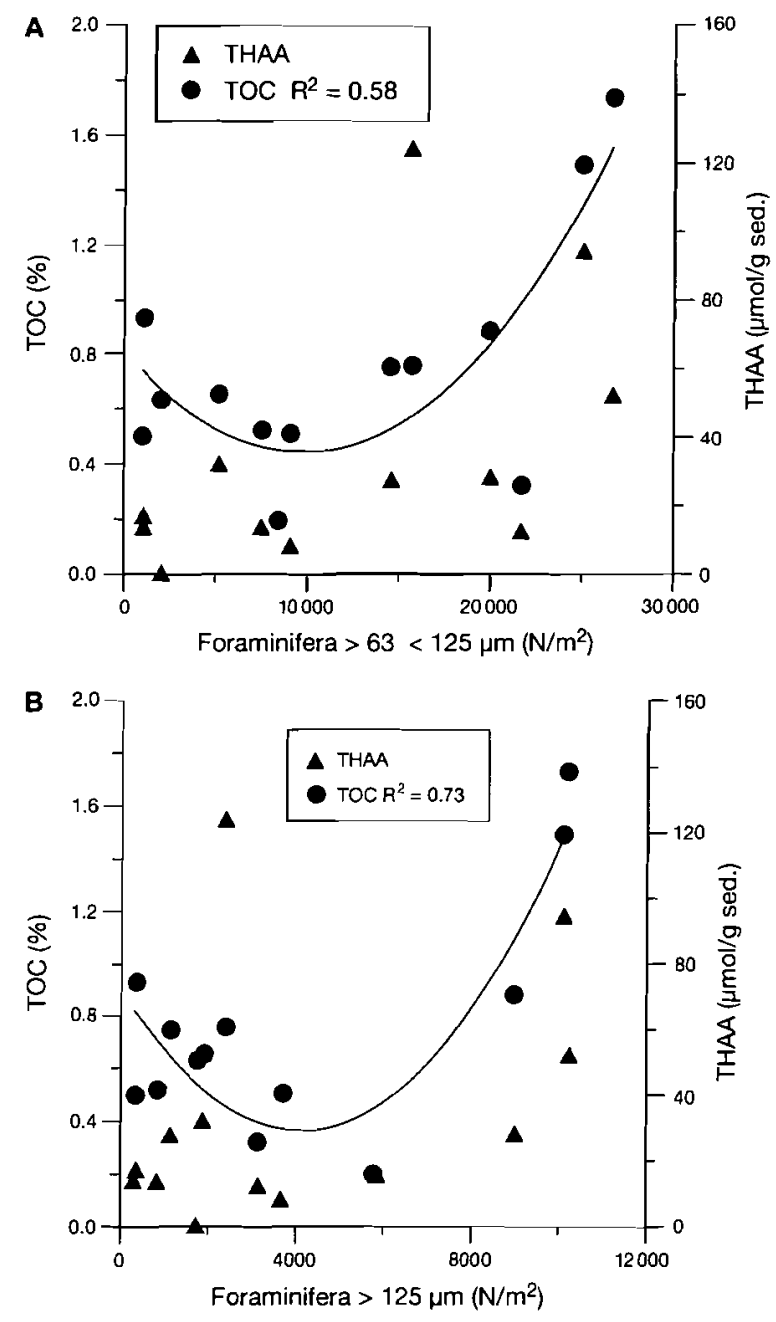

Fig. 7. Relationships between TOC and THAA and abundance of foraminifera in 2 size-classes

\section{DISCUSSION}

Abundance and biomass of the various benthic compartments decreased with increasing water depth along the Barents Sea slope, as described for other deep-sea regions (Thiel 1979, Rowe et al. 1991, Deming \& Yager 1992, Tietjen 1992, Tselepides \& Eleftheriou 1992, Flach \& Heip 1996). The only correlation between increasing depth towards the deeper central Eurasian Basin and decreasing faunal abundance was found for macrofauna. In contrast, bacterial and all faunal compartments followed a significant trend of decreasing numbers with increasing latitude. The dominance in abundance of the smallest size-groups (bacteria and $>63$ to $<125 \mu \mathrm{m}$ foraminifera) in the deep basins, and the dominance of the meiofauna at the ridges, was, however, in accordance with Thiel's (1979) hypothesis. Biomass was dominated by macrofauna on the Barents Sea shelf and slope and at the Lomonosov Ridge, but within the deep basins and on the Gakkel Ridge bacterial and foraminiferal biomass became more important than that of the larger size-groups. Furthermore, microbial investigations in 1996 at the Lomonosov Ridge showed that bacterial biomass made up only $20 \%$ of the microbial biomass, suggesting that a large fraction of other small heterotrophs was present (Soltwedel \& Schewe 1998).

Bacterial communities changed from the Barents Sea slope towards the Lomonosov Ridge (Kröncke et al. 1994): small cocci and filamentous cells decreased in abundance, whereas short rods only decreased towards the Gakkel Ridge and then increased again to a constant level in the Makarov Basin. Large coccoid cells were more abundant on the ridges and slopes. Our study revealed a significant relationship between bacterial abundance and TOC. Kröncke et al. found a

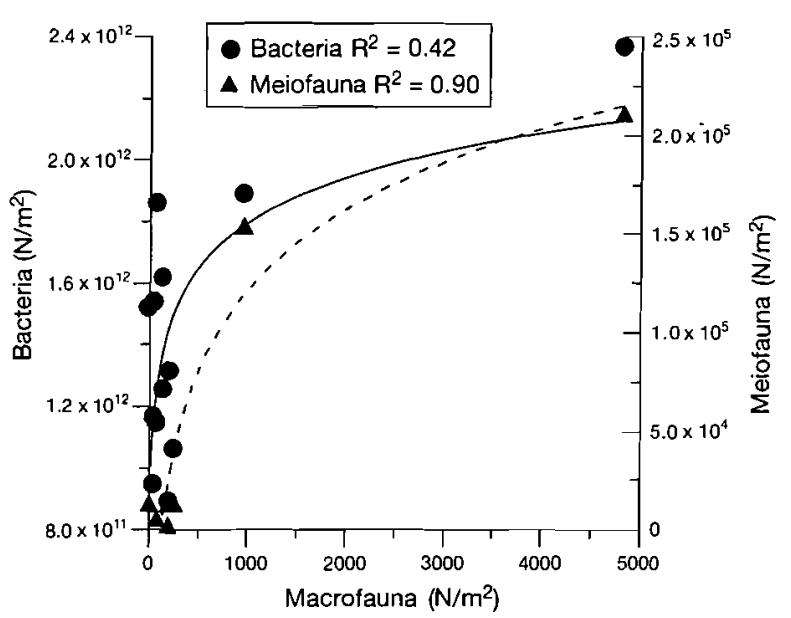

Fig. 8. Relationships between abundances of bacteria, meiofauna and macrofauna 
significant correlation between the biomass of small coccoid cells and small rods and TOC in the surface sediment layer. In general, bacterial activity appears to be limited in cold polar regions (Pomeroy \& Deibel 1986, Boetius \& Lochte 1996).

No significant difference in meiofauna abundance and biomass was detected between different water depths in the Arctic Ocean. Abundance and biomass of meiofauna was only slightly related to bacterial density; significant correlations were found with both size classes of foraminifera, macrofauna and TOC. The nematode communities were mainly dominated by detrivorous-bacterivorous species, which provides evidence for the importance of the microbial-loop in the oligotrophic benthic system (Boetius \& Lochte 1996, Vanreusel et al. 2000).

The distribution pattern of the foraminifera revealed highest abundance in the vicinity of the Barents Sea slope, where a high amount of infaunal species occurred in the top $4 \mathrm{~cm}$ of the sediment. Wollenburg \& Mackensen (1998b) explained the occurrence of infaunal species as related to the supply of phytodetritus. No correlation between distribution pattern and physical parameters could be found in the present study. This is usual for foraminifera (Pak et al. 1992, Bergsten 1994). The obvious relationship between abundance of both foraminiferal size-groups and bacteria and meiofauna supports the idea that the microbial loop as well as food supply and competition mainly control the distribution of foraminifera in the investigation area.

Food availability also appears to determine the structure of macrofaunal communities in the deep Arctic Ocean, as has been demonstrated for the western parts of the Eurasian Arctic Ocean (Kröncke 1994, 1998). Macrofaunal communities of the basins and ridges differed as a function of differences in the feeding mode of the fauna. Suspension-feeders were dominant on the ridges, and deposit-feeders in the basins. The significant correlations found between the abundances of bacteria, foraminifera and meiofauna, as well as bacteria, meiofauna and macrofauna, reflect either 2 distinct food chains or competition for the same food source. The first hypothesis is in accordance with the suggestions of Rowe (1996) that food-limited systems such as the Arctic Ocean are more likely to follow the food-chain model than the food-web model, since there is not enough food to share or to compete for.

Correlations between the benthic compartments and food items were generally rather poor. The best fits were for the abundance of bacteria and meiofauna and TOC on a $1 \%$ significance level and for foraminifera and macrofauna on a $5 \%$ significance level. These relationships may result from the fact that especially the small groups are able to respond to an influx of fresh organic material (Graf 1989, Turley \& Lochte
1990, Gooday et al. 1992, Linke 1992, Pfannkuche 1993, Linke et al. 1995) as well as to convert more refractory organic material into biomass (Gooday et al. 1992, Boetius \& Lochte 1996). Weak correlations between higher trophic groups and food items can be attributed to the exploitation of sudden food-supply pulses and the food-chain or food-web structure (Rowe et al. 1991, Tietjen 1992).

As stated earlier, primary production is low and restricted to the upper $100 \mathrm{~m}$ of the water column (Wheeler et al. 1996). Sedimentation rates are also low (Stein et al. 1994b). Nevertheless, Wollenburg \& Kuhnt (2000) have clearly shown that the benthic foraminifera communities of the central Arctic Ocean are driven by the availability of fresh organic material. Using a much larger data set than in the present study, they found high correlation coefficients between organic carbon-flux and both living and dead foraminifera. For the Lomonosov Ridge, Rudels et al. (1994) and Steele \& Boyd (1998) described a frontal system where Eurasian and Canadian water masses meet, which might provide the deep-sea benthos with food through higher primary production (Nürnberg 1996). This hypothesis is confirmed by the generally lower ice concentration and larger areas of ice-free waters at the Lomonosov Ridge, as demonstrated by satellite images (Gloersen et al. 1992). Large areas of ice-free waters were also found during our investigations in 1991. In these areas, there is enhanced primary production and sedimentation and increased organic material released from melting sea-ice. Finally, lateral transport of organic material by intermediate water masses, described by Aagard et al. (1985) and Rudels et al. (1994), also provides the Gakkel and the Lomonosov Ridge with organic material from the Barents Sea and the Siberian shelf (Stein et al. 1994b, Boetius et al. 1996a). According to Stein et al. (1994a), the organic material in the central Arctic Ocean originates from the Siberian shelf, is mainly of terrigenous origin, and is highly refractory.

Based on the good correlations found between the abundance of the various benthic compartments and Rowe's (1961) hypothesis, the results of Wollenburg \& Kuhnt (2000) necessitate a refinement of Rowe's hypothesis: i.e. different size classes compete for fresh organic material when it is available; when it is not available, the refractory organic material in the central Arctic Ocean is transformed by bacteria (Boetius \& Lochte 1996), and thereby transferred to higher trophic levels.

Recent investigations by Soltwedel \& Schewe (1998) in 1996 revealed high concentrations of chloroplastic pigments for the Eurasian slope of the Lomonosov Ridge and in the Amundsen Basin. Their findings confirm our hypothesis of high sedimentation rates along the Lomonosov Ridge. Because of differences in the 


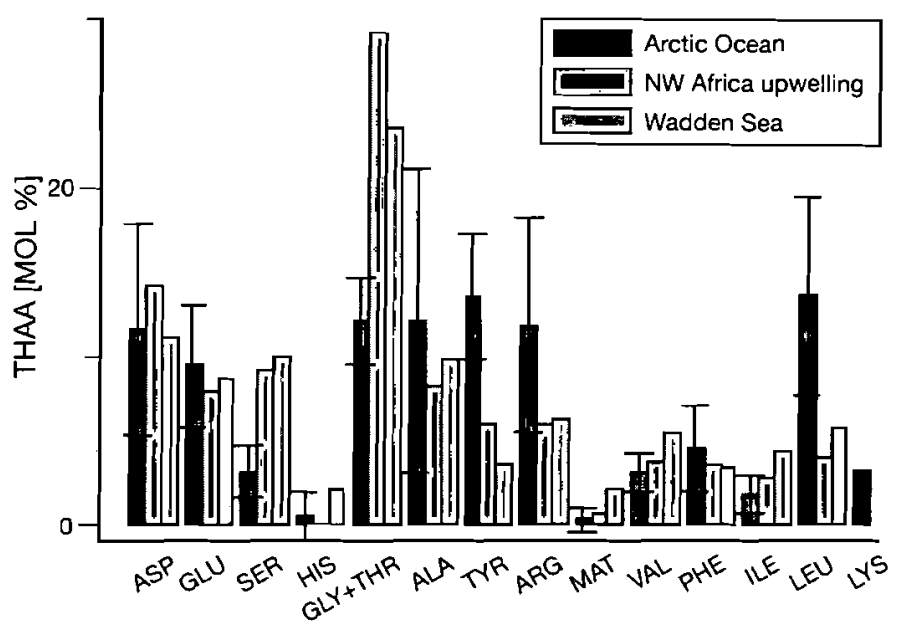

Fig. 9. Mean molar composition of THAA in Arctic Ocean surface-sediments. Data for Wadden Sea (Behrends 1997) and NW African upwelling area sediments (Müller 1975) are shown for comparison

analytical methods, we cannot compare our 1991 data directly to their 1996 data. Nevertheless, changes in the content of chlorophyll pigments in the central Arctic Ocean can be taken as the first indication of a biological response to the influence of climate-driven changes in the hydrographic system of the Arctic (Carmack et al. 1997, Morison et al. 1998, Steele \& Boyd 1998). Carmack et al. (1997), Morison et al. (1998) and Steele \& Boyd (1998) described a higher inflow of Atlantic water masses into the central Arctic Ocean since the late 1980s that was characterised by increased salinities, especially in the Amundsen Basin. This inflow of warmer Atlantic water masses could enhance primary production and sedimentation of fresh organic material in the central Arctic Ocean, thereby providing the benthic compartments with food.

The amino acid composition of the sediments of the Arctic Ocean in 1991 differed significantly from that of other areas, mainly in high relative concentrations of arginine, alanine, thyrosine and leucine (Fig. 9). Especially the composition of amino acids at Stn 2177 at the top of the Lomonosov Ridge and at Stn 2184 in the Makarov Basin was different from that in other areas. Since only weak correlations were found between THAA and the various benthic compartments, amino acids cannot be used as indicators for food supply.

Our results show that the abundance of bacteria, meiofauna and foraminifera in our study area was 1 to 2 magnitudes lower than that of other deep-sea areas around the world, e.g. Venezuela Basin, Demerara Abyssal Plain, Cape Verde Basin, Porcupine Seabight, Coral and Salomons Seas (see Tietjen 1992) or the Goban Spur area (Heip et al. 2000). Macrofauna abundance from the deep Arctic Basins, including the
Gakkel Ridge, was generally lower than in the above areas and comparable only to very deep regions of the Cape Verde Basin or the Coral and Salomons Seas. In the Mediterranean deep sea, similar low macrofauna abundance was also found (Fiege et al. 2000). Therefore, we stress that the greater part of the Arctic Ocean is an extreme oligotrophic environment-a 'desert', dominated numerically by bacteria and other small heterotrophs as in other deep-sea areas (Tietjen et al. 1989, Rowe et al. 1991). Rowe (1996) modelled the influence of the presence or absence of different benthic size classes on the transfer of organic carbon through the benthic system. In contrast to other deepsea areas, in which a bimodal shift in size-groups parallels an increase in mobile megafauna and fishes and also in microbiota (Haedrich \& Rowe 1977, Tietjen et al. 1989, Rowe et al. 1991), very few megafauna and fishes have been found in trawls from deep-Arctic basins (E. Rachor pers. comm.). Summarizing, the less food-limited ridges of the Arctic Ocean seem to play a similar role for food supply and for the carbon cycle as the trenches in the Mediterranean deep-sea (Boetius et al. 1996b). Our findings confirm the extreme oligotrophic nature of the Arctic Ocean.

\section{LITERATURE CITED}

Aagard K, Swift J, Carmack K (1985) Thermohaline circulation in the Arctic Mediterranean Seas. J Geophys Res 90: 4833-4846

Andersen OGN (1989) Primary production, chlorophyll, light, and nutrients beneath the Arctic sea ice. In: Herman $Y$ (ed) The arctic seas: climatology, oceanography, geology and biology. Van Nostrand Reinhold, New York, p $147-191$

Alexander V (1980) Interrelationships between the seasonal sea ice and biological regimes. Cold Reg Sci Technol 2: $157-178$

Behrends B (1997) Aminosäuren in Sedimenten und Partikeln des Wattenmeeres. PhD thesis, Oldenburg University, Oldenburg

Behrends B, Liebezeit G (1999) Particulate amino acids in Wadden Sea waters-seasonal and tidal variations. J Sea Res 41:141-148

Bergsten $\mathrm{H}$ (1994) Recent foraminifera of a transect from the North Pole to the Yermak Plateau, eastern central Arctic Ocean. Mar Geol 119:251-267

Boetius A, Lochte K (1996) High proteolytic activities of deepsea bacteria from oligotrophic polar regions. Arch Hydrobiol (Spec Issue) 48:269-276

Boetius A, Grahl C, Kröncke I, Liebezeit G, Nöthig EM (1996a) Distribution of plant pigments in Eastern Arctic sediments: indication of recent marine organic matter input. Ber Polarforsch 212:213-218

Boetius A, Scheibe S, Tselepides A, Thiel H (1996b) Microbial biomass and activities in deep-sea sediments of the eastern Mediterranean: trenches are benthic hotspots. DeepSea Res 43:1439-1460

Carmack EC, Aagard K, Swift JH, Macdonald RW, Mclaughlin FA, Jones EP, Perkin RG, Smith JN, Ellis KM, Killius LR (1997) Changes in temperature and tracer distributions 
within the Arctic Ocean: results from the 1994 Arctic Ocean section. Deep-Sea Res (II)44:1487-1502

Deming JW, Yager PL (1992) Natural bacterial assemblages in deep-sea sediments: towards a global view. In: Rowe GT, Pariente $V$ (eds) Deep-sea food chains and the global carbon cycle. Kluwer Academic Publishers, Dordrecht, p 11-28

Fiege D, Kröncke I, Barnich R (2000) High abundance of Myriochele fragilis Nilsen \& Holthe, 1985 (Polychaeta: Oweniidae) in the deep sea of the Eastern Mediterranean. Hydrobiologia (in press)

Flach E, Heip C (1996) Vertical distribution of macrozoobenthos along the continental slope of the Goban Spur Area (NE Atlantic). Mar Ecol Prog Ser 141:55-66

Fütterer DK (1992) ARCTIC ' 91 : the expedition ARK-VIII/3 of RV 'Polarstern' in 1991. Ber Polarforsch 107:1-267

Gloersen P, Campbell WJ, Cavalieri DJ, Comiso JC, Parkinson CL, Zwally HJ (1992) Arctic and Antarctic sea ice, 1978-1987: satellite passive-microwave observations and analysis. NASA SP-511, National Aeronautics and Space Administration, Washington

Gooday AJ, Levin LA, Linke P, Heeger T (1992) The role of benthic foraminifera in deep-sea food webs and carbon cycling. In: Rowe GT, Pariente V (eds) Deep-sea food chains and the global carbon cycle. Kluwer Academic Publishers, Dordrecht, p 63-91

Graf G (1989) Benthic-pelagic coupling in a deep-sea benthic community. Nature 341:437-439

Haedrich R, Rowe G (1977) Megafaunal biomass in the deep sea. Nature 269:141-142

Heip C, Duineveld G, Flach E, Graf G, Helder W, Herman P, Lavaleye $M$, Middelburg $J$, Pfannkuche $O$, Soetaert $K_{1}$ Soltwedel $T$, de Stigter $H_{1}$ Thomsen $L$, Vanaverbeke $J$, de Wilde P (2000) The role of the benthic biota in sedimentary metabolism and sediment-water exchange processes in the Goban Spur area (N.E. Atlantic). Deep Sea Res (II: Spec Vol OMEX) (in press)

Kolatschek J, Eicken H, Alexandrov VY, Kreyscher M (1996) The sea-ice cover of the Arctic Ocean and the Eurasian marginal seas: a brief overview of present day patterns and variability. Rep Polar Res 212:2-18

Koltun VM, Blakschin LL (1964) Scientific results of the highIatitude oceanographic expeditions into the northern part of the Greenland Sea and adjacent areas of the Arctic basins. 'Transport' Publisher, Moskau, Leningrad, p 5-78 (in Russian)

Kröncke I (1994) Macrobenthos composition, abundance and biomass in the Arctic Ocean along a transect between Svalbard and the Makarov Basin. Polar Biol 14:519-529

Kröncke I (1998) Macrofauna communities in the Amundsen Basin, at the Morris Jesup Rise and at the Yermak Plateau (Eurasian Arctic Ocean). Polar Biol 19:383-392

Kröncke I, Tan TL, Stein R (1994) High benthic bacteria standing stock in deep Arctic basins. Polar Biol 14:423-428

Linke P (1992) Metabolic adaptations of deep-sea benthic foraminifera to seasonally varying food input. Mar Ecol Prog Ser 81:51-63

Linke P, Altenbach A, Graf G, Heeger T (1995) Response of deep-sea foraminifera to a simulated sedimentation event. J Foram Res 25:75-82

Morison J, Steele M, Andersen R (1998) Hydrography of the upper Arctic Ocean measured from the nuclear submarine U.S.S. Pargo. Deep-Sea Res (I) 45:15-38

Müller PJ (1975) Diagenese stickstoffhaltiger organischer Substanzen in oxischen und anoxischen marinen Sedimenten. 'Meteor' Forsch Ergebn C 22:1-60

Nürnberg D (1996) Biogenic barium and opal shallow Eura- sian shelf sediments in relation to the pelagic Arctic Ocean environment. In: Stein R, Ivanov GI, Levitan MA, Fahl K (eds) Surface-sediment composition and sedimentary processes in the central Arctic Ocean and along the Eurasian continental margin. Ber Polarforsch 212:96-118

Pak DK, Clark DL, Blasco SM (1992) Late Pleistocene stratigraphy and micropaleontology of a part of the Eurasian Basin (= Fram Basin), central Arctic Ocean. Mar Micropaleont 14:1315-1325

Paul AZ, Menzies RJ (1974) Benthic ecology of the high Arctic deep-sea. Mar Biol 27:251-262

Pfannkuche $O$ (1993) Benthic response to the sedimentation of particulate matter at the BIOTRANS station, $47^{\circ} \mathrm{N}$, $20^{\circ} \mathrm{W}$. Deep-Sea Res 40:135-149

Pomeroy L, Deibel D (1986) Temperature regulation of bacterial activity during the spring bloom in Newfoundland coastal waters. Science 233:359-361

Rowe GT (1996) The cycling of organic matter in food limited environments. Biosyst Ecol Ser 11:233-260

Rowe $\mathbf{G}$, Sibuet $M$, Deming $\mathbf{J}$, Khripounoff A, Tietjen NJ, Macko S, Theroux R (1991) Total sediment biomass and preliminary estimates of organic carbon residence time in deep-sea benthos. Mar Ecol Prog Ser 79:99-114

Rudels B, Jones EP, Anderson LG, Kattner G (1994) On the intermediate depth waters of the Arctic Ocean. Geophys Monogr 85:33-46

Salzwedel H, Rachor E, Gerdes D (1985) Benthic macrofauna communities in the German Bight. Veröff Inst Meeresforsch Bremerh 20:199-267

Scott DB, Vilks G (1991) Benthonic foraminifera in the surface sediments of the deep-sea Arctic Ocean. J Foram Res 21 : $20-38$

Soltwedel T, Schewe I (1998) Activity and biomass of the small benthic biota under permanent ice-coverage in the central Arctic Ocean. Polar Biol 19:52-62

Steele M, Boyd T (1998) Retreat of the cold halocline layer in the Arctic Ocean. J Geophys Res 103:10419-10435

Stein R, Grobe H, Wahsner M (1994a) Organic carbon, carbonate, and clay mineral distributions in eastern central Arctic Ocean surface sediments. Mar Geol 119:269-285

Stein R, Schubert C, Vogt C, Fütterer D (1994b) Stable isotope stratigraphy, sedimentation rates, and salinity changes in the Latest Pleistocene to Halocene eastern central Arctic Ocean. Mar Geol 119:333-355

Thiel $H$ (1979) Structural aspects of the deep-sea benthos. Ambio Spec Rep 6:25-31

Thompson DH (1982) Marine benthos in the eastern Canadian High Arctic: multivariate analyses of standing crop and community structure. Arctic 35:61-74

Thorndike AS, Colony R (1985) Sea ice motion in response to geotropic winds. J Geophys Res 87:5845-5852

Tietjen JH (1992) Abundance and biomass of metazoan meiobenthos in the deep sea. In: Rowe GT, Pariente V (eds) Deep-sea food chains and the global carbon cycle. Kluwer Academic Publishers, Dordrecht, p 45-62

Tietjen J, Deming J, Rowe G, Macko S, Wilke R (1989) Meiobenthos of the Hatteras Abyssal Plain and Puerto Rico Trench: abundance, biomass and associations with bacteria and particulate fluxes. Deep-Sea Res 36:1567-1577

Tselepides A, Eleftheriou A (1992) South Aegean (Eastern Mediterranean) continental slope benthos: macroinfaunalenvironmental relationships. In: Rowe GT, Pariente $\mathrm{V}$ (eds) Deep-sea food chains and the global carbon cycle, Kluwer Academic Publishers, Dordrecht, p 139-156

Turley CW, Lochte K (1990) Microbial response to the input of fresh detritus to the deep-sea bed. Palaeogeogr Palaeoclim Palaeoecol 89:3-23 
Vanreusel A, Clough LM, Jacobsen K, Ambrose W, Jivaluk J, Ryheul V, Herman R, Vincx M (2000) Meiobenthos of the central Arctic Ocean. Deep-Sea Res (in press)

Wassmann P, Peinert R, Scharek R (1991) Patterns of production and sedimentation in the boreal and polar Northeast Atlantic. Polar Res 10:209-228

Wheeler PA, Gosselin M, Sherr E, Thibault D, Kirchman DL, Benner $R$, Whitledge TE (1996) Active cycling of organic carbon in the central Arctic Ocean. Nature 380:697-699

Wollenburg $\mathrm{J}$ (1995) Benthic foraminiferal assemblages in the Arctic Ocean: indicators for mass distribution, productivity and sea ice drift. Ber Polarforsch 179:1-227

Editorial responsibility: Otto Kinne (Editor),

Oldendorf/Luhe, Germany
Wollenburg JE, Kuhnt W(2000) The response of benthic foraminifers to carbon flux and primary production in the Arctic Ocean. Mar Micropaleont (in press)

Wollenburg JE، Mackensen A (1998a) Modern benthic foraminifers from the central Arctic Ocean: faunal composition, standing stock and diversity. Mar Micropaleont 34: 153-185

Wollenburg JE, Mackensen A (1998b) On the vertical distribution of living (Rose Bengal stained) benthic foraminifers in the Arctic Ocean. J Foram Res 28:268-285

Zenkevitch L (1963) Biology of the Seas of the USSR. George Allen \& Unwin Ltd, London

Submitted: July 19, 1999; Accepted: November 16, 1999 Proofs received from author(s): May 22, 2000 